\title{
Enhancing The Development Of Competencies: the role of $\mathrm{UBC}$
}

\author{
Carmen Delia Dávila Quintana, José-Ginés Mora, Pedro J. Pérez \\ \& Luis E. Vila
}

\section{Introduction}

Researchers and policy makers in Europe have recently been paying closer attention to the relevance of University Business Cooperation (UBC) as a powerful tool for improving the innovative capacity of the productive sector and, hence, promoting economic growth and sustainability. Most of this attention has focused on diverse aspects of technology or knowledge transfer procedures. A well-known body of literature analyses UBC in knowledge transfer according to the hypothesis that the research activities of universities, especially applied research, have a relevant impact on economic development (Link \& Rees, 1990; Mansfield, 1991; Santiago et al., 2008; Davey et al., 2011b; Etzkowitz, 1998, 2003; Melink et al, 2014). Yet the interest in knowledge transfer activities has diverted the attention from another relevant fact: the main economic contribution of universities to aggregate economic well-being is the 'production of individuals' with the right competencies to support the evolution of the economy now and in the future. The contribution of higher education graduates to social and economic wellbeing has been extensively examined in the literature on private and social rates of return, but their contribution to the transformation of the economy is broader than the rates of return they provide. The contribution of graduates to increase the capacity for innovation, for technological change and, in general, the wider non-monetary benefits of higher education should also be taken into account (Vila, 2000; Melink et al., 2014). All these aspects are even more relevant in the global knowledge economy. Hence, recent trends in UBC have emerged, emphasising the need to develop cooperation between universities and companies in order to make the teaching and learning processes better adapted to the changing needs of society in general and the productive sectors in particular. Recent publications and seminars are paying increasing attention to the role of UBC in developing human capital with the right skills that the new society and the new global economy are demanding (Goddard, 2011; Wilson, 2012). Following this approach, this article analyses and clarifies whether and how existing UBC modes could be expanded to the core field of higher education without explicitly tailoring degrees and curricula to the precise knowledge needed for specific companies.

We review UBC from the perspective that the competencies developed by the flow of new graduates emerging each year from higher education institutions (HEIs) is one of the key contributions of higher education to the aggregate capacity for increasing the productivity of the economies and, consequently, one of the main drivers of sustainable economic growth and social and economic well-being.

\section{Higher Education and the New Global Innovation Economy}

From an economic viewpoint, higher education is seen as an investment that pays returns through its effects on productivity. Individuals and society allocate a 
substantial volume of resources to HEIs because they are thought to exert a decisive influence on peoples' lives and living conditions. Higher education institutions influence aggregate economic productivity in three main ways. First, a substantial proportion of the effort in research and development, both basic and applied, occurs within the higher education system. Second, research universities instruct those who will later work professionally in the research projects and programmes that are oriented towards the generation of new useful knowledge. Third, as HEIs also instruct an increasing share of workers, the employee-driven innovation approach emphasises the relevance of the innovative behaviour of those employees who are not specifically assigned to the generation and implementation of new ideas and knowledge. The premise here is that the propensity of individuals to take part in innovative activities at the workplace requires that they develop a set of specific skills and competencies during their studies (Schmidt \& Gibbs, 2009). In the next subsections, we first summarise the theoretical views about the economic value of $\mathrm{HE}$, second, the graduates' economic functions, and third, how their competencies determine their behaviour in the economy.

\section{Higher Education and the Economy: Theoretical Views}

The effects of higher education investment in the economy have been examined by the economic growth theory and the human capital theory. Neo-classical growth theory (Solow, 1956) initially describes the output of a firm as a function of inputs, capital and labour, with knowledge acting as an exogenous force that enhances labour effectiveness. Human capital theory postulates that education makes individuals more productive, contributing to output generation (Schultz, 1961; Becker, 1962; Mincer, 1974). Accordingly, the initial growth model expanded to incorporate human capital as a third input factor. The enhancement of human capital will lead to growth by increasing the efficient use of available resources. In addition, endogenous growth models show that economic growth emerges in the economic system as a direct result of internal economic processes. The first version of endogenous growth theory (Romer, 1986) does not make an explicit distinction between capital accumulation and technological progress. Later versions recognise that intellectual capital is distinct from physical and human capital. Physical capital accumulates through savings, and human capital accumulates through education, whilst intellectual capital, the source of technological progress, accumulates through innovation. The most prevalent model of technological change is the knowledge production function (Griliches, 1979), where innovative activity is expressed as a function of R\&D inputs, human capital inputs and spillovers. The creation of technology requires the allocation of resources to $R \& D$ activities whereby the new ideas appear.

The presence of knowledge-related spillovers highlights the crucial role of physical location regarding innovative performance and economic growth. In this line, the 'innovation systems' approach (Lundvall, 1992) to productivity gains emphasises the relevance of the environment: elements such as institutional arrangements, geographic specialisation, demographic structure, and other environment characteristics should have a decisive influence both on the spatial distribution of inventive performance and on the path of knowledge assimilation in diverse territorial units. The findings suggest that the capacity for innovation of diverse territories emerges mainly from individual and corporate interaction in terms of synergies and 
networks. The influence of technical agencies, research infrastructures, education and training systems, governance structures, and local innovation policies (Iammarino, 2005) also helps to explain territorial differences in innovative performance.

\section{Graduates as Equilibrators and Innovators}

Why, and through what mechanisms, do graduates contribute more to the economy than those with lower levels of education? The literature suggests that it is because they have a higher propensity to act both as equilibrators and as innovators (Lundvall, 2008).

Individuals operate as equilibrators when they react to disequilibria either in the markets of input factors or in those of final goods. Following the disequilibrium theory (Schultz, 1975), the efficiency of individual responses to disequilibria depends on the 'allocative ability' which is an expression of personal investments in human capital that emerges from formal education and accumulated life and work experience. Early recognition of market disequilibria enables graduates to be more efficient when reallocating resources. According to this argument, the 'capacity to deal with disequilibrium' is the main component of the 'allocative ability' that is needed to accurately evaluate changing economic conditions, generate comparative advantages in economic activities and, therefore increase productive efficiency whenever resources are reallocated to reach new equilibria.

In addition, graduates contribute to economic growth by acting as innovators, i.e. when they are able to generate market disequilibria by deliberately introducing newly available ideas and knowledge in the economic activities. Lucas' (2009) model considers technological change in the economy as the product of a wide class of educated problem-solving producers. The industrial revolution involved the emergence and rapid expansion of a widening class of educated people who spent their entire careers exchanging ideas, solving work-related problems, generating new knowledge and finding the means to apply that flow of newly generated ideas and knowledge in economic activities. The model builds on the premise that all knowledge resides in the head of individuals so that the knowledge of a firm, or economy, or any group of people is simply a compilation of the knowledge possessed by its members. A main feature of the model is the social, collaborative character of intellectual activity. In this light, productivity growth at national level is mainly an ongoing intellectual achievement, a sustained flow of new ideas that are applied to production of goods and services to satisfy human needs in the country.

\section{Graduates' Competencies and Behaviour}

When individuals confront changes in economic conditions, even if they generated the changes themselves, they will be able to understand the challenges posed by those changes and to find sound solutions. The capacity of graduates to act as equilibrators and innovators in the economy seems to be the main distinctive feature of their economic behaviour compared to those with lower educational achievement. The question arises of knowing what determines the capacity of individuals to evaluate changing economic conditions accurately, to generate advantages by using new knowledge in production and, consequently, to gain efficiency.

Research on the determinants of innovation at the workplace is expanding considerably in the wake of West and Farr's (1990) operational definition of innovation as the deliberate introduction and application of new ideas, processes, products, or 
procedures designed to yield benefits for the production agent that adopts this new knowledge. Broadly speaking, in order to make a productivity-enhancing change, a sequence of four activities is necessary. When conditions change, first, someone must perceive a problem and become aware of the opportunity, or recognise the need for improvement (detection). Second, it is necessary to create, develop, or discover and adapt at least one new idea that could tentatively solve the problem (proposal). Third, there is a need to evaluate the new proposed ways as a better solution than the old ways of doing things (evaluation). Finally, it is necessary to apply resources in accordance with the newly adopted solution (reallocation) and therefore generate an increase in the productivity for the individual or the organisation. Accordingly, graduates' main contribution to the economy depends on their participation and level of performance in a kind of process involving a sequence of diverse activities undertaken continuously through the life cycle of individuals, a process that reaches their professional, economic and personal environments (Cooper, 1998). Hence, they must be able to perform well through the whole process of detection, proposal, evaluation and reallocation activities required to generate innovation that triggers productivity increases. We believe that UBC can contribute to a more effective higher education by enhancing the development of those capabilities. Furthermore, we believe that the styles of teaching and learning that are used during university studies are crucial for students to develop the specific competencies required to act, once graduates, as effective equilibrators and innovators in the economy, and that UBC can contribute to identify the key competencies and to implement the most effective teaching and learning modes to develop them.

The degree of competency development through higher education amongst graduates appears as the outcome of the production process that combines the educational resources deployed by higher education institutions and students' personal resources, including their dedication to study, the skills acquired before higher education, and their natural talents (Hartog, 2001). To understand the challenges for higher education, one must take into account that graduates learn by doing, using and interacting when acting as innovators and dealing with market disequilibria (OECD, 2011). Moreover, the economic behaviour of working graduates is the result of a combination of individual and environmental factors. Anderson et al. (2004), King and Anderson (2002), West (2002), and more recently Belloc (2012) provide comprehensive overviews of the literature on the determinants of innovation performance at the organisation level. Summarising the main findings, innovation performance at the corporate level depends on organisational, work group and individual factors. Organisational factors include the structure and size of the organisation, organisational strategy, the resources available, and the predominant organisational culture. Work group elements that influence innovation include team structure and climate, traits of the team members, team processes, and decision-making approaches, as well as the most prevalent leadership style. Various individual factors seem to promote or limit corporate innovation: personality traits, sources and types of individual motivations, indicators of employees' cognitive ability, as well as observable job characteristics. Empirical research on the impacts of individual factors on innovation performance often focuses on the functions of managers and manager characteristics in corporate innovation. The findings provide evidence that knowledge management capacity mediates the relation between strategic human resources practices and corporate innovation performance. 
Though extensive research looks into the impacts of some individual factors on corporate performance, only a few studies analyse the competency profile of individuals who show a high propensity for involvement in activities that lead to diverse productivity-enhancing outcomes at the firm level. However, the understanding of innovation processes at the organisation level needs to encompass the effects of different individual capabilities on the willingness of all employees-and not only managers - to use novel ideas and knowledge to generate diverse types of innovation in working environments.

The teaching activities of HEIs focus on helping students to understand and master the academic theories, methods and areas of knowledge and contribute to their cultural enrichment and to the development of their personality. Additionally, higher education studies should prepare students for future work and participation in other spheres of life. The teaching activities of HEIs should aim at establishing the basis of relevant knowledge in order to enable students to understand and acquire, or develop up to the right levels, the right set of competencies and skills that will be necessary in their forthcoming professional and personal lives. Today, higher education institutions are challenged to offer smart responses to the accelerated changes taking place in society as a whole, and more particularly in the economy and at the workplace.

\section{How Can UBC Contribute To Training People With The Right Skills?}

Research on the relationships between higher education and graduate employment points out that, generally speaking, higher education is unlikely to prepare graduates for their future job tasks and responsibilities. Teichler (2015) identified some practical reasons that prevent a much closer match between higher education and employment needs: the imperfections in identifying both the job requirements and the job-seekers' abilities, the unavoidable time gap between the identification of new job requirements and the provision of the respective competencies, and the dynamics in the quantitative development of occupations. Taking into account these practical limitations, much closer attention should be paid to UBC that seeks medium- and long-term solutions in the ways of teaching and learning used in higher education, mostly at undergraduate level, and the system of lifelong learning provided by HEIs.

\section{A Model of Teaching and Learning that is More Adjusted to Social and Economic Demands}

The gap between the competencies required of graduates and the knowledge that is traditionally transferred to students by HEIs has been central in guiding European policy makers towards more efficient and effective higher education systems. The competencies acquired by the flow of new graduates are an expression of the multidimensional output obtained from the resources allocated to HEIs. Amongst other competencies that graduates bring to their workplaces there is the specific capacity to generate productive innovation, both by creating knowledge and by adapting knowledge recently acquired by others, and the capacity to use it to perform their tasks and responsibilities in novel ways that increase their own and, consequently, aggregate productivity. 
There is a worldwide trend to rethink HE, motivated by the need for students to acquire the specific knowledge of their disciplinary specialisation, and to ensure that they are prepared for present and future requirements of the companies and the economy as a whole. Specifically, the EC Communication 'Rethinking Education' (European Commission, 2012) points out that, whilst the youth unemployment rate in 2012 was close to $23 \%$, at the same time there were over 2 million job vacancies that could not be filled. It concluded that Europe needed a radical rethink on how education and training systems could deliver people with the skills demanded by the labour market. Employability as defined by Knight and Yorke (2002) should be one of the objectives of the higher education system. However, current trends in citizenship education and higher education policy analyse the conflicts between the concepts of employability and democratic citizenship, and highlight the risks for the civic and democratic functions of universities when higher education is valued mainly in terms of its labor market and economic outcomes (Dezelan \& Pavlin, 2014).Promoting graduate employability means identifying the kind of competencies that will be in high demand now and in the future. Several studies have tried to disclose the skills demanded by business (Hodges \& Burchell, 2003). A general conclusion is that, although each employer is looking for employees with specific abilities and skills to perform well in particular jobs, there are certain competencies that are almost universally sought after and appreciated by companies. Examples are communication skills, capacities for team work, problem solving, capacity to innovate, taking initiatives and leadership. It seems that the most required competencies in the graduate labour market, besides the specific competencies of each degree or curricula, are some non-cognitive generic competencies. Heckman et al. (2006) provide extensive empirical support to this idea.

Usually, teachers at HEIs are well trained to transmit specific knowledge that is related to their area of disciplinary expertise. Yet their ability to help students to develop those generic competencies connected to labour market needs is, in general, more limited as a logical consequence of the lack of experience of academics in the productive sectors. For this reason, UBC becomes a useful strategy to overcome skills deficit.

How can UBC contribute to the development in HE of those other noncognitive competencies that are in demand and are highly appreciated by the business sector? There is a wide consensus that the learning process takes place mostly through the active behaviour of students (Tyler, 1949), i.e. what students do is more important in determining what they are learning than what the teacher does (Shuell, 1986). There is general agreement amongst educators that proactive teaching and learning styles are more effective in developing competencies and generating a truly valuable learning outcome than traditional lessons (For an extensive overview of literature sympathetic with this idea, see Biggs (2011)).

In general, there is no clear understanding of how to foster non-cognitive skills in $\mathrm{HE}$ classrooms at the same time as the lecturer develops the specific contents of the course. In an educational production function framework (Todd \& Wolpin, 2003) competency development is viewed as an educational outcome emerging from students' personal resources (motivation, effort, human capital...) and the resources provided by the HEIs (libraries, equipment, teachers...). Educational outcomes are expected to be more valuable when more resources are devoted to $\mathrm{HE}$. Another possibility is to look, not at the quantitative volume of educational 
resources, but at the emphasis laid on diverse teaching and learning modes during the delivery of study programmes.

One competency that is greatly demanded by work organisations is the capability to generate productive innovation. In this line, Vila et al. (2012) found that the teaching and learning modes deployed during HE were a key determinant of the individual development of the four competencies required to innovate when the other elements involved held constant. In general, proactive teaching and learning modes during higher education studies do not promote the acquisition of competencies for innovation in the same way. In particular, project or problem-based learning and group assignments show a stronger impact on the development of these competencies, suggesting that approaching new problems in collaboration with others fosters differently the acquisition of innovation capabilities. Dávila et al. (2010) offer very similar findings when analysing data on graduates in Latin American countries. A growing body of research supports the use of collaborative methods and problem-based learning. In a meta-analysis of 82 studies, Walker and Leary (2009) found that problem-based learning outperformed traditional methods in terms of outcomes development.

Vila et al. (2014) studied how higher education could contribute to the development of the potential of future graduates to innovate at their workplace as part of their day-to-day duties. Regarding the effects of competencies on individual potential for innovation, the main results suggest that only a few specific competencies have a significant marginal influence on the individual probability of being involved in innovate activities at the workplace. Not surprisingly, amongst the competencies with a greater impact of the individual propensity to innovate at the workplace, there are three skills that the managerial literature points out as having a prominent role in the innovation outcomes at corporate level, namely: alertness to new opportunities, ability to mobilise the capacities of others, and the ability to come up with new ideas and solutions. In a recent paper, Dávila et al. (2014) examined the role of teaching and learning in the development of a feature that is greatly appreciated by work organisations: leadership. The results show that what happens during graduates' higher education experience in terms of the development of specific competencies exerts a crucial influence on their future performance as leaders in work environments. In particular, the results highlight the importance of some specific competencies for the leadership behaviour of graduates. Amongst these are the four competencies related to the innovation capacity: alertness to new opportunities, mobilising the capacities of others, coming up with new ideas and solutions, and willingness to question one's own and others' ideas. Other specific competencies related to leadership behaviour are the capacity to assert one's authority, making one's meaning clear to others, and the ability to coordinate activities. The authors recommend that if we wish to develop the leadership potential of future graduates, we should intensify the use of specific combinations of teaching and learning modes in higher education, including group assignments, oral presentations, written assignments, internships and work placements. The main implication of the analysis for managerial practice is that an effective way to foster the innovative orientation of organisations is to pay attention not only to organisational structures, but also to specific competencies of those on the payroll.

According to existing evidence, UBC should emphasise the prevalence of those proactive teaching and learning styles that have an impact on the capacities required to lead innovation in the workplace. A recent document (European Commission, 
2014) is an excellent summary of strategies implemented in Europe to support UBC in the field of education. Numerous benefits are identified, from strengthening the levels of human capital to stimulating entrepreneurship through teaching and learning, or stimulating innovation processes or new pedagogy.

Another relevant way at system level is the cooperation of the business sector in curriculum design. Such practices have been encouraged by the curricular reforms that have been taking place in Europe during the construction of the European Higher Education Area. It was common practice in Germany that external representatives of the world of work become members of the review committees for individual study programmes, that academic staff had been employed in industry, and that students had worked part-time in activities related to possible future work. Universities of applied sciences in The Netherlands have traditionally cooperated closely with industry, but this has now been extended to all universities. In Italy and Spain, ministries published decrees that included the obligation for universities to consult enterprises or other potential future employers when designing new programmes of study in order to implement the Bologna Process (Detmer et al., 2010).

\section{A Dynamic and Flexible System of Continuing Education to Retrain People as Social and Economic Conditions Evolve}

A number of factors, such as rapid technological change, the challenge to increase competitiveness, and the need to stand out in the market whilst becoming international in scope, explain the demand for a workforce that is ever more knowledgeable and skilled. In order to find and hold jobs, workers increasingly must improve their basic skills and obtain new qualifications, and up-skill or re-skill. To this end, university-based lifelong learning programmes are more and more necessary, given the ageing of the population and the need to maintain employability until a later retirement age.

Due to rapid changes in the market, the uncertainties of unemployment, and the new socio-economic and demographic conditions, graduates are subject to the risks of flexible labour markets (Brown et al., 2011). It is therefore no surprise that continuing education and permanent training are necessary to facilitate the transitions between jobs in different businesses, from one job to another within a firm, or simply to keep one's current job. Continuing education also helps people to move from unemployment to employment, and there are lifelong learning programmes whose principal objective is to renew and update knowledge, competence and skills in order to adapt to the changing labour environment. It is in post-secondary lifelong learning that UBC should play an important role, helping to re-shape what has been termed the 'third mission' of HEls. This can be part of the university's structure, or alternatively, universities can collaborate with other organisations to set up permanent networks. One of the objectives of UBC concerning permanent training is to contribute to the sustainable employability of adult professionals, who thus maintain a connection with their peers and their professional environment. Universities should offer programmes that respond to the specific needs of businesses and the labour market. To do so, they must involve employers, employers' organisations, and specific professional groups in the development of continuing higher education study programmes. Additionally, HEIs should invite and encourage employers to participate in teaching in a blended learning environment. Programmes already exist with both academics and professionals as teachers, in some cases in equal proportions (Houston \& Osborne, 2013). 
Students enrolled in tertiary lifelong learning programmes come from diverse backgrounds. They include young graduates, senior workers, workers with identified gaps in skills, and firm managers. In many instances, their need for training arises because of the ability of businesses to identify key missing skills, to mobilise them quickly, and to encourage their acquisition by all employees who will use them. Adult participation in continuing education and training is a critical aspect in the maintenance of quality of life and work and has become part of active labour market policies (Palier, 2006).

At the European level, two surveys provide data on adult participation in lifelong learning: the Labour Force Survey (LFS) and the Adult Education Survey (AES). According to the results of the LFS in 2013, 10.5\% of the European adult population (aged between 25 and 64 years) participated in formal or non-formal education and training during the four weeks prior to the survey, whilst the AES shows that, in $2011,40.3 \%$ of adults aged 25-64 in Europe took part in formal or non-formal learning activities in the 12 months before the survey. The AES shows that non-formal education and training is six times more prevalent than formal education $(36.8 \%$ against $6.2 \%)$.

Several factors influence adult participation levels in lifelong learning, in particular, educational attainment, employment status, occupational category and age. According to the AES survey, in 2011, more employed persons in the EU engaged in educational and training activities than those who were unemployed or inactive. Amongst the employed, the proportion of those engaged in on-going learning was higher amongst those with the highest degrees. In the EU, $61.3 \%$ of those with university degrees or equivalents enrolled in some continuing learning in 2011, whether formal or informal. Participation rates were especially disappointing for low-skilled and older adults and were higher amongst younger adults and those with postsecondary education. Apparently, permanent education, needed to improve and update skills and knowledge and attract those who already had a high level of skills. Both surveys reached this conclusion, as did the OECD Survey of Adult Skills (PIAAC) on adult participation in education and training whose main objective was to understand how adults developed, used at the workplace and benefited from their skills. It attempts to measure the level of competency of adults in literacy, mathematics and problem-solving in technology-rich environments. The results show that $20 \%$ of the EU working age population have low levels of literacy and numeracy skills, whilst $25 \%$ lack the skills to effectively make use of ICTs to solve problems. The survey also points out the existence of a 'low skills trap' because low-skilled adults are less likely to participate in learning activities, with the consequent deterioration of their already low skills level. The level of skills is effectively related to employability, labour market participation, income, health, and other aspects of well-being. A large share (20\%-25\%) of the EU adult population with low levels of key skills represents a real challenge for policy makers and for the educational system. A greater involvement of political authorities would therefore be necessary to assist those with lower skills or poor training to take advantage of continuing learning opportunities. Universities for their part must adapt and offer courses that are better targeted to the specific needs of those who want them and are more closely attuned to the labour market.

In $2011,9 \%$ of those in the AES survey who had completed post-secondary (also known as tertiary) education in the EU28 stated that one obstacle to participation in lifelong learning was the lack of an available 'suitable education or training activity'. This statistic and the fact that formal education institutions, including universities, 
are not the main providers of lifelong learning in the EU28 point to the important role that universities have to play in this field. 'Formal education institutions' in 2011 offered only $9.8 \%$ of non-formal education and training activities, whereas employers offered $32 \%$ and 'non-formal education and training institutions' offered $17.7 \%$.

In the EU, within all occupational groupings, including labourers, there is a clear trend of an increasing number of jobs at the upper and lower levels (following the ISCO classification) on the one hand, and stagnation or even decrease of new jobs at the middle levels on the other (CEDEFOP, 2010). Universities should place greater emphasis on bringing the worlds of education and work together and addressing the growing need for training that these trends indicate.

Another area for collaboration between universities and businesses is hinted at by the many job advertisements in which employers mention qualities beyond outstanding grades and scientific or technical knowledge. These are 'soft' or transverse skills and cover a range of practical and personal abilities, from critical thinking and problem solving to communication, conflict resolution, time and project management skills, foreign languages, and presentation and IT skills. They may also include a work ethic, independence, responsibility, initiative, team spirit and creativity, aspects that were identified by Rothstein et al. (2008). Some, such as teamwork, independence, and negotiating are frequently honed outside the classrooms through practical experience, internship and apprenticeship.

The transition to a university that is less hermetic and corporative, and more collaborative is now easier thanks to Massive Open Online Courses (MOOCs) which provide free higher education courses, online, and with no enrolment restrictions or physical barriers. They are proliferating fast, growing in popularity and interest and changing the nature of the learning environment' (European Commission, 2013). The MOOC business model has proliferated since its beginnings in the 2000 decade, and today there are numerous examples. The more relevant are: Academic Earth, ALISON, Canvas Network, China Open Resources for Education, Edulanka, MIT OpenCourseWare, Khan Academy, OpenLearn, Peer to Peer University; whilst in the 2010s, the most outstanding are: Codecademy, Coursera, Crash Course, Duolingo, EduKart, edX, ewant, FutureLearn, iversity, Open2Study, OpenHPI, OpenLearning, NovoEd, Udacity, Udemy, and xuetangX, amongst others. They foster simultaneously massive retraining, curricular updating, and the use of new technologies. Nonetheless, the success of remote and blended kinds of teaching and learning requires the validation and recognition of MOOC accreditation in order to be fully effective.

Whatever the forms of collaboration chosen by universities and businesses for education and training, lifelong learning has become a global international strategy (Jacobi, 2009) and must always keep in mind its ultimate goal: the development of an inclusive society and the encouragement of equal opportunities.

\section{Concluding Remarks}

The new role of HEls and the different kinds of cooperation with businesses are well summarised in the conclusions of the last University-Business Cooperation Forum (2014):

Renewing the modes for learning (collaborative learning, solving of real-life problems, teamwork, work-based learning, professional mentoring, etc.) 
requires highly professionalised teaching staff in universities, with openness and flexibility in adapting to new approaches as well as the recruitment of new teaching actors like teachers, tutors and trainers from industry (professors of practice). The availability of alternative learning pathways (e.g. internships, reverse mentoring, part-time studies, non-traditional BA-MA pathways, dual or double major study degrees) is leading to the university losing its centrality as a learning venue.

Businesses should play a more prominent role in UBC concerning education and training, and universities would benefit from the input of business contacts with improvements in curricular design and study programmes and the design of teaching content and materials. Other benefits for academics include the following: the university is brought into contact with the business and institutional reality around it; the university receives income; scholars are more likely to interact with colleagues in industry; and universities may find partners for collaboration (as in mixed technological or research projects). Students also benefit from UBC by becoming involved in innovative and entrepreneurial activities (e.g. internships, conferences, research projects, seminars, etc.) and applying their knowledge and experiencing apprenticeship in the real world, and by a work experience under 'protected' conditions that facilitates a transition to the world of work and makes them more employable. This collaboration presents several benefits for the company: it gets access to skilled potential employees; it gets the chance to develop contact networks with academics for future collaborative research; and its teacherprofessionals are enhanced by the didactic model known as learning by teaching.

The key to the success of the programmes is in the co-development of curricula, accreditation, and evaluation by HEIs and business. In turn, that co-development requires the implementation of regulatory frameworks that are conducive to effective UBC and implies facilitating the participation of business representatives in universities, and of academics and students in business activities by removing bureaucratic barriers, simplifying administrative procedures, and reducing the administrative costs of participation in relevant initiatives.

Universities should plan a university-wide system for UBC that encompasses all fields of study and subject areas and develop the strategic, structural and human capacity for UBC in the field of education, including the provision of career incentives for academics to be involved in UBC activities, the diversification of funding sources, and the adjustment of fundraising strategies.

The acquisition of competencies required to innovate at the workplace and elsewhere depends on the prevalent use of some pro-active teaching and learning modes in higher education. Problem-based learning, facts and practical knowledge, participation in research projects, internships and work placements emerge as the most effective ways. At the same time, traditional scholastic modes of teaching and learning seem to contribute little, if anything, to the development of the competencies required to innovate and to lead innovation, although they may be more effective in developing other important competencies, such as the mastery of the field. Businesses could create specialised departments for collaboration with HEIs and encourage the development of corporate initiatives and programmes that focus on those specific competency needs of the firm's workers that are likely to be refined by students' higher education experiences. At the same time, work organisations could cooperate more actively in curricular development and delivery by 


\section{European Fournal of Education, Part I}

establishing joint study programmes at both undergraduate and graduate levels and cooperating by providing more company placements and internships for students. Both partners will need to improve their cooperation and change their way of thinking (Schmidt \& Gibbs, 2009). Companies should encourage the recognition of students' work experience for qualifications and integration in curricula by establishing closer communication and cooperation with university career offices in the definition and delivery of programmes and courses.

Carmen Delia Dávila Quintana, University of Las Palmas de Gran Canaria, Campus de Tafira s/n, 35017 Las Palmas de Gran Canaria, Spain, delia.davila@, ulpgc.es

Fosé-Ginés Mora, UCL-Institute of Education, 20 Bedford Way, London WC1H

oAL, UK, F.Mora@ioe.ac.uk

Pedro F. Pérez, University of Valencia, Avenida de Blasco Ibáñez 13, 46010

Valencia, Spain, pedro.j.perez@uv.es

Luis E. Vila, University of Valencia, Avenida de Blasco Ibáñez 13, 46010 Valencia, Spain,luis.vila@uv.es

\section{REFERENCES}

Anderson, N., De Dreu, C. K. \& Nijstad, B. A. (2004) The routinization of innovation research: a constructively critical review of the state-of-thescience, Fournal of Organizational Behavior, 25, pp. 147-173.

BECKER, G. S. (1962) Investment in human capital: a theoretical analysis, The Fournal of Political Economy, 70, pp. 9-49.

BELLOC, F. (2012) Corporate governance and innovation: a survey, fournal of Economic Surveys, 26, pp. 835-864.

Biggs, J. B. (2011) Teaching for Quality Learning at University: what the student does (McGraw-Hill Education).

Brown, P., Lauder, H. \& Ashton, D. (2011) The Global Auction: the broken promises of education, jobs, and incomes (Oxford, Oxford University Press).

CEDEFOP (2010) Skills Supply and Demand in Europe: medium-term forecast up to 2020. (Luxembourg, Publications Office of the European Union). http:// www.cedefop.europa.eu/EN/Files/3052_en.pdf

CoOper, J. R. (1998) A multidimensional approach to the adoption of innovation, Management Decision, 36, pp. 493-502.

Davey, T., BaAken, T., Galan Muros V. \& Meerman A. (2011a) The State of European University- Business Cooperation. Final Report - Study on the Cooperation between Higher Education Institutions and Public and Private Organisations in Europe. http://bookshop.europa.eu/en/the-state-of-european-universitybusiness-cooperation-pbNC0213081/

Davey, T., Baaken, T., Deery, M. \& Galan Muros, V. (Eds) (2011b) 30 Good Practice Case Studies in University-Business Cooperation. Science to Business Research Centre E European Commission (Münster, DG for Education and Culture). http://www.ub-cooperation.eu/pdf/casestudyreport.pdf

DÁvilA, C.D., MorA, J. G. \& Vila, L.E. (2010) Competencias para la innovación en las universidades de América Latina: un análisis empírico, Revista Iberoamericana de Educación Superior, 1, pp. 5-23. 
DÁvila, C.D., Mora, J. G. \& Vila, L.E. (2014) Competencies which shape leadership, International fournal of Manpower, 35, pp. 514-535.

Detmer, A., MorA, J.G., \& VieIRA, M.J. (2010) Good Practices in University Enterprises Partnership. Gooduep project, Valencia.

Dezelan, T. \& PAVlin, S. (2014) The challenges of employability and citizenship in education. Towards a holistic understanding, Annales. Ser. hist. sociol. 24, pp.363-670. http://zdjp.si/wp-content/uploads/2015/08/dezelanpavlin.pdf

ETzKowitz, H. (1998) The norms of entrepreneurial science: cognitive effects of the new university-industry linkages, Research Policy, 27, pp. 823-833.

ERKowitz, H. (2003) Innovation in innovation: the Triple Helix of universityindustry-government relations, Social Science Information, 42, pp. 293-337.

EuROPEAN COMMISSION (2012) Communication Rethinking Education https:/ec. europa.eu/digital-agenda/en/news/communication-rethinking-education

EUROPEAN COMMISSION (2013) 5th University-Business Forum. Strategic Partnerships for Innovation and Growth: from dialogue to partnerships. Forum Report. http://ec.europa.eu/education/tools/docs/ubforum-5_en.pdf

EUROPEAN COMMISSION (2014) Measuring the Impact of University-Business Cooperation (European Commission, DG EAC). http://ec.europa.eu/education/news/2014/20140604-cooperation_en.htm.

GodDARD, J. (2011) Connecting Universities to Regional Growth: a practical guide (DG EAC, EC).

GRILICHES, Z. (1979) Issues in assessing the contribution of R\&D to productivity growth, Bell Fournal of Economics, 10, pp. 92-116.

HARTOG, J. (2001) On human capital and individual capabilities, Review of Income and Wealth, 47, pp. 515-540.

HeCKMAN, J. J., LJUNGE, M., \& RAGAN, K. (2006) What are the key employment challenges and policy priorities for OECD countries?, Vortrag bei der OECDMinisterkonferenz Boosting Jobs and Incomes. Toronto, June 15.

Hodges, D. \& Burchell, N. (2003) Business graduate competencies: employers' views on importance and performance, Asia-Pacific Fournal of Cooperative Education, 4, pp. 16-22.

Houston, M. \& Osborne, M. (2013) Teaching \& Learning in Tertiary Learning for People in Mid-life. (Barcelona, Oldenburg). http://themp.eu/sites/default/ files/userfiles/shared/ebooks/e-Book_Teaching\%26Learning.pdf

IAMMARINO, S. (2005) An evolutionary integrated view of regional systems of innovation: concepts, measures and historical perspectives, European Planning Studies 13, pp. 497-519.

JACOBI, A. (2009) International Organizations and Lifelong Learning (London, Palgrave Macmillan).

KING, N. \& ANDERSON, N. (2002) Managing innovation and change: a critical guide for organizations (Cengage Learning EMEA).

KNIGHT, P.T. \& YORKE, M. (2002) Employability through the curriculum, Tertiary Education and Management, 8, pp. 261-276

LINK, A.L., \& REES, L. (1990) Firm size, university based research, and the returns to R\&D, Small Business Economics, 2, pp. 25-31.

LUCAS, R. E. (2009) Ideas and growth, Economica, 76, pp. 1-19.

LundVAlL, B. A. (1992) National Systems of Innovation: towards a theory of innovation and interactive learning (London, Pinter). 
LundVAlL, B. A. (2008) Higher education, innovation, and economic development, in: Annual World Bank Conference on Development Economics 2008, Regional: Higher Education and Development (Washington DC, World Bank).

MANSFIELD, E. (1991) Academic research and industrial innovation, Research Policy, 20, pp. 1-22.

Melink, M., Pusnik, T. \& PAVlin, S. (2014) Emerging Modes of Cooperation between Private Enterprises and Universities - Insights of European Enterprises and Employers Organisations (Ljubljana, EMCOSU project report). http:// www.emcosu.eu/static/uploaded/files/outcomes/01_EMCOSU_International_ Report.pdf.

MINCER, J. A. (1974) Schooling and earnings, in: Schooling, Experience, and Earnings, pp. 41-63 (Massachusetts, NBER).

OECD (2011) Skills for Innovation and Research (Paris, OECD Publishing).

PALIER, B. (2006) The Re-orientation of European Social Policies, International Politik und Gesellschaft. 1/2006. http://library.fes.de/pdf-files/id/ipg/03644. pdf

RoMER, P. M. (1986) Increasing returns and long-run growth, Fournal of Political Economy 94, pp. 1002-1007.

RothsteIn, R., JACOBSEN, R. \& WildeR, T. (2008) Grading Education: getting accountability right (Washington, DC, Economic Policy Institute \& New York, Teachers College Press).

Santiago, R., Carvalho, T., \& Relva, R. (2008) Research and the universities' image, European fournal of Education, 43, pp. 495-512.

SCHMIDT, R. \& GIBBS, P. (2009) The challenges of work-based learning in the changing context of the European Higher Education Area, European fournal of Education, 44, pp. 399-410.

Schultz, T. W. (1961) Investment in human capital, The American Economic Review, 51, pp. 1-17

SCHULTZ, T. W. (1975) The value of the ability to deal with disequilibria, fournal of Economic Literature, 13, pp. 827-846.

ShuElL, T. J. (1986) Cognitive conceptions of learning, Review of Educational Research, 56, pp. 411-436.

Solow, R. M. (1956) A contribution to the theory of economic growth, The Quarterly Fournal of Economics, 70, pp. 65-94.

TeICHLER, U. (2015) Higher education and the world of work: the perennial controversial debate, in: J.C. SHIN et al (Eds) Mass Higher Education Development in East Asia (Springer International Publishing). pp. 269-288.

TodD, P. E. \& WolPIN, K. I. (2003) On the specification and estimation of the production function for cognitive achievement, The Economic Fournal, 113(485), F3-F33.

TYLER, R. W. (1949) Achievement testing and curriculum construction, in: G. Williamson (Ed) Trends in Student Personnel Work (Minneapolis, University of Minnesota Press), pp. 391-407.

UNIVERSITY-BUSINESS COOPERATION FORUM (2014) Universities, Businesses E Co.: together we can; strategic inter-sectoral partnerships for economic and social change and growth. Rome, 2-3 October 2014. http://ec.europa.eu/education/ tools/docs/ub-forum-rome-report.pdf

VILA, L. E. (2000) The non-monetary benefits of education, European fournal of Education, 35, pp. 21-32. 
Vila, L. E., PÉRez, P. J. \& Morillas, F. G. (2012) Higher education and the development of competencies for innovation in the workplace, Management Decision, 50, pp. 1634-1648.

Vila, L. E., PÉreZ, P. J. \& Coll-Serrano, V. (2014) Innovation at the workplace: do professional competencies matter?, Fournal of Business Research, 67, pp. 752-757.

WEST, L. L. (2002) Best practices in integrating technology into adult ESL instruction: a literature search (Sacramento County Office of Education). http://www. intelecom.org/ilrn/adult/crc/crcpdf/TECH21_ESLTech_3. pdf.

West, M. A. \& FARr, J. L. (Eds) (1990) Innovation and Creativity at Work: psychological and organizational strategies (Chichester, Wiley).

WALKER, A. \& LEARY, H. (2009) A problem-based learning meta analysis: differences across problem types, implementation types, disciplines, and assessment levels, Interdisciplinary fournal of Problem-based Learning, 3, pp. $12-43$.

Wilson, T. (2012) A review of Business-University Collaboration (London, Department for Business, Innovation \& Skills). 